Special Announcements 


\section{Special Announcements}

\section{FROM AUSTRIA}

The following statement is included in this issue of the Yearbook at the special request of Leo Bernardis, of Europahaus in Vienna: ${ }^{1}$

Auf Grund des in der Rechtssache Prof. Dr. Fellner - Europahaus Wien zur Zahl $24 \mathrm{Cg}$ 550/69 ergangenen rechtskräftigen Urteiles des Landesgerichtes für ZRS Wien erklären wir, daß der in der Publikation über Vorträge des VII. Internationalen Seminars, herausgegeben von Dr. Josef Varga, Europahaus Wien, enthaltene Beitrag des Herrn Universitätsprofessors Dr. Fellner eine, ohne dessen Wissen abgedruckte, von ihm vor dem $A b$ druck auch nicht eingesehene und vom Herausgeber willkürlich gekürzte und unkorrigierte Wiedergabe einer Tonbandaufzeichnung eines frei gehaltenen Vortrages ist. Das Europahaus Wien war nicht autorisiert, diesen Vortrag zu veröffentlichen und trägt daher die alleinige Verantwortung für alle darin enthaltenen Fehler.

\section{FROM THE UNITED STATES AND CANADA}

\section{Austrian Ministry of Education Scholarships}

The Austrian ministry of education will grant a limited number of scholarships for the academic year 1972-1973 to American graduate students now working on doctoral dissertations or other research projects in the field of Austrian history. The grants cover only the cost of tuition and maintenance for one person and may not be used to supplement a stipend received from another scholarship or fellowship. Holders of these scholarships are expected to be in residence at an Austrian university and should have a good command of the German language.

${ }^{3}$ As a general rule, the editor of the Yearbook believes that all material published in American journals should be written in or translated into English. In this particular instance, however, he is departing from this general practice because he does not wish to run the risk of changing the meaning of the text in any possible way. It is almost impossible to translate material from German into English without changing the exact meaning or altering the fine nuances of the original text in some way or another. 
Candidates wishing to apply should send a letter of application, together with transcripts, letters of recommendation, and an outline of their research project, directly to William A. Jenks, Department of History, Washington and Lee University, Lexington, Virginia 24450.

The deadline for applications is November 15, 1971.

Washington and Lee University

WILLIAM A. JENKS

\section{Prize for Best Article on Central European History}

The first biennial prize of the Conference Group for Central European History for the best article dealing with Central European history published during the years 19691970 was awarded to Kenneth Barkin, of the University of California at Riverside, for his article on "Adolph Wagner and German Industrial Development," which was published in 1969 in The Journal of Modern History. Honorable mention was given to the following: (1) Lamar Cecil, of the University of North Carolina at Chapel Hill, for his essay "The Creation of Nobles in Prussia, 1871-1918," published in The American Historical Review in 1970; (2) Gerald Feldman, of the University of California at Berkeley, for his analysis of the "Fondements sociaux de la mobilisation économique en Allemagne (1914-1916)," published in the Annales in 1969 ; (3) Konrad $H$. Jarausch, of the University of Missouri at Columbia, for his evaluation of "The Illusion of Limited War: Chancellor Bethmann Hollweg's Calculated Risk, July 1914," published in 1969 in Central European History; and (4) Michael H. Kater, of Joseph E. Atkinson College of York University, for his report on "Die Ernsten Bibelforscher im Dritten Reich," published in the Vierteljahrshefte für Zeitgeschichte in 1969.

\section{Personnel}

On December 28, 1970, William A. Jenks, of Washington and Lee University, was selected as Robert A. Kann's successor as executive-secretary of the Committee to promote Studies of the History of the Habsburg Monarchy. At the same time, Istvan Deak, of Columbia University, was elected for a sixyear term to replace Prof. Kann as a member of the committee. The other members of the committee are Charles Jelavich, of 
Indiana University; Enno E. Kraehe, of the University of Virginia; Wayne S. Vucinich, of Stanford University; and Piotr S. Wandycz, of Yale University.

Also on the evening of December 28, 1970, Gordon A. Craig, of Stanford University, was elected chairman of the Conference Group for Central European History. Andreas Dorpalen, of Ohio State University, was elected vice-chairman; Robert G. L. Waite, of Williams College, secretary-treasurer; and Paul W. Schroeder, of the University of Illinois, member of the executive board. The executive board of the Conference Group is now composed of the above officers and Henry Turner, of Yale University; Douglas Unfug, of Emory University; and $R$. John Rath, of Rice University. 